\title{
Meeting the needs of gifted and talented students through technology supported distance teaching
}

\author{
Catherine McLoughlin and Ron Oliver \\ Edith Cowan University
}

\begin{abstract}
In 1997 an initiative by the Education Department of Western Australia extended the use of audiographic conferencing to provide for talented and gifted students in rural Western Australia. In addition to increasing the access and participation of rural and isolated students to a special curriculum designed to extend and enrich their learning, the initiative also aimed to extend and develop the applications of technology for gifted students. For these students, the goal of higher order thinking was sought as a learning outcome. Based on observations and research on the actual classrooms where audiographic conferencing was used to mediate learning, this paper suggests that higher order thinking among students can be fostered by utilising audiographic conferencing to create a classroom milieu of peer discourse, investigation and visual display of ideas. Teachers were encouraged to support the skills of negotiation, verbal elaboration and peer revision of ideas and to utilise the two-way audio and video elements of the technology to maximise learning. The initial evaluation of the project for gifted and talented students indicated that the interactive features of the technology provided the possibilities for task-related collaboration and gave students the opportunity to interpret, discuss and evaluate concepts, thereby leading to higher order thinking.
\end{abstract}

\section{Background to the study}

In 1997 an initiative was taken by the Education Department of WA (EDWA) to extend the Academic Talent Program via telematics delivery. The curriculum to be delivered, while covering the core curriculum areas, was also intended to enrich and extend students, and to develop independent thinking strategies. The stated aims of the curriculum as laid down in the Curriculum Framework (EDWA, 1996) documents was to develop both content knowledge and understandings and to enrich students so that they could demonstrate a range of higher level cognitive skills such as: 
- the ability to access and synthesise information;

- a knowledge of the ways in which language varies according to content, purpose, audience and context;

- the capacity to work collaboratively;

- the capacity to develop reasoned arguments about interpretation and meaning;

- the capacity to develop reasoned arguments about interpretation and meaning;

- the capacity to apply problem-solving capacities in a purposeful ways, including situations requiring critical thinking; and

- the capacity to apply solving approaches in various contexts;

- an appreciation of the ways in which language varies according to context.

- the capacity to plan and organise activities, sort out priorities and monitor one's own performance.

Teachers were expected to develop these competencies in students while teaching via audiographic conferencing, in a networked synchronous environment. In the research, teachers were observed and monitored as they worked towards achieving higher order thinking outcomes with their students.

The immediate context of the study was a cluster of 5 telematics classrooms of Western Australia, where audiographic conferencing was used extensively for delivery of programs in Maths, Science, Italian, Social Studies and English (McLoughlin, Oliver \& Wood, 1997). Delivering to several sites simultaneously, teachers used the resources offered by the technology and combined these with both pedagogy and curriculum objectives. This paper reports a research study which sought to explore ways to assist the teachers to utilise the technology in ways which were able to achieve the higher order thinking outcomes that were stated explicitly in the curriculum documents. In addition, through collaborative research partnership with teachers, the researchers aimed to assist in the development of practical strategies which would complement the curriculum orientation and teaching approaches that were already in place.

\section{Rationale for the study}

The rationale for the study was to support students in the achievement of higher order thinking outcomes and to develop pedagogies for the particular contexts of the schools involved in the distance education 
program. In Western Australia, audiographic conferencing is used for delivery of curricula to students in rural and remote areas. This form of delivery is likely to continue and be augmented by other conferencing technologies as rural schools continue to expand and offer specialised programs for gifted and talented students.

Despite the fact that over 100 schools in Western Australia are served by the audiographics program, little attention has been given to the actual social interactions and applications of technology or to the nature of teaching in this form of distance teaching. Nevertheless, discussion of the unique character of audiographics teaching and learning are in evidence. Burge \& Roberts (1993) report on the potential of this technology to support collaborative, visual learning and an "extended classroom " model of teaching. In another study, Gunawardena (1992, p. 61) reports that "two-way interactive telecommunication systems such as audiographics provide opportunities to develop learner-controlled instructional systems that make frequent interaction mandatory for effective learning experiences". In the Australian context, Oliver \& McLoughlin (1997, p. 51) report a study which found that telematics learning environments had low levels of learner control and learner autonomy, and that lessons were strongly teacher directed. The authors concluded that "few teachers used instructional models that would enable them to promote higher order learning outcomes". These findings are consistent with an earlier study conducted by Oliver \& Reeves (1994) where interactions tended to be centred on low level questions and exchange of information, rather than engagement in tasks which involved problem solving and reasoning.

In a later study by McLoughlin, Oliver \& Wood (1997), it was proposed that both a pedagogic framework and a socially based classroom model can be used to reconceptualise teaching and learning. Given the intrinsically verbal and aural nature of teaching and learning via audiographics, research that examines the different communicative and interactive functions of talk is imperative, as these interactions support the teaching-learning relationship, define roles and influence how and what students learn. By investigating participant roles, the research focus planned to take on a different perspective, described by Greeno (1997) as 'participation structures'. This meant looking closely at how teachers and students interact, as it is through these interactions that most learning outcomes are achieved. 
Methods of instruction are not only instruments for acquiring skills; they are also practices in which students learn to participate. In these practices, students develop patterns of participation that contribute to their identities as learners, which includes the way they take initiative and responsibility for their learning (p.12).

One aspect of the research was therefore to examine the patterns of interaction that occurred and the manner in which they were supported by technology, in order to understand how student-collaboration was supported and maintained, and how this was fostered by the technology and by teacher pedagogy. The study was based on actual teaching encounters and events over the duration of one academic year, and traced the evolving skills of the students at expressing ideas, reasoning, explaining and engaging in collaborative discourse. It also monitored the communicative strategies used by teachers in fostering higher order cognition.

\section{Learning and theories of social interaction}

If it is accepted that learning in technology supported environments is a socially organised educational activity involving talk, interaction and dialogue between learners and adults or expert teachers, it follows that there are different ways of conceptualising learning in directions that connect it with the social world, with language and with culture. For Laurillard (1995) this means the adoption of a communicative model of education, in which knowledge is a negotiated commodity. Like sociocultural theory, Laurillard's conversational framework provides a social and communicative perspective on teaching and learning. Learning is culturally influenced and a social rather than an individual process. Vygotsky believed that "human learning presupposes a specific social nature and a process by which children grow into the intellectual life of those around them" (Vygotsky, 1978, p. 89). Language plays a vital role in enabling the learner to participate and communicate with others, and so talk and interaction are therefore essential to learning (McLoughlin \& Oliver, 1997).

In audiographics classrooms these elements are vital to the success of the lesson, and are recognised in the socio-interactionist perpectives on learning (Crook, 1994). The second theoretical concept associated with the socio-cultural framework is the use of tools and signs to mediate learning about the world. According to Vygotsky (1978) signs include language, mnemonics, mathematics language, art and diagrams etc. Tools on the other hand, mediate forms of interaction with the 
environment and support problem solving and development of understanding. Such technologies as computers are part of the communication process in many classrooms, and they are also part of the social fabric of learning as they support interaction and provide a focus for discussion by enabling sharing of ideas, visual display and collaboration. Technology use was therefore regarded as integral to the classrooms of the study, as it supported dialogue, interaction and sharing of ideas.

\section{Planning for higher order thinking}

Several elements were identified by the researchers as important to the design of the learning environment for talented and gifted student learning in the classrooms of the study. Firstly, teachers needed to have a clear idea of what higher level thinking entailed, and how it could be supported in discourse and dialogue. It was proposed that teachers adopt a socio-communicative theory of learning and teaching, which supported the curriculum outcomes, but with the added dimension of collaborative reasoning and verbal expression. An emphasis on communication appealed to teachers, and provided a sound basis for these telematics classrooms, as listening and speaking skills were fundamental to the effective use of the technology. Secondly, the adoption of a collaborative dialogue model (Burge \& Roberts, 1993) provided teachers with a broader and socially based perspective on learning, where learners contributed to, and supported the learning process, and technology acted to bridge the distance. It was characterised by fundamental changes in perspective from:

- a view of learning confined to the classroom and controlled by the teacher, to one of a learning environment which was supportive, extended and distributed, consisting of a community of learners;

- a view of technology as a tool or as a teacher, to a view of computers as resources which could display creative ideas, provide a resource for inquiry, and extend thinking by bringing together students from different locations;

- a view of learning as individualised, to one which was communicative, shared and dynamic;

- a preoccupation with teaching "content" to multiple sites simultaneously to allocating responsibility to small groups for self monitoring and sharing of ideas, and analysing content, ideas and experiences. 
Adoption of the extended classroom model encouraged teachers to create opportunities for higher order thinking by giving students more responsibility for their learning and by fostering communication between remote sites using the communications networks. Teachers were able to oversee social interaction in groups to ensure that there was equal participation between the remote schools. In addition, creative forms of leadership where students took control were encouraged, rather than teacher initiated discourse.

Thirdly, a clear focus on learners as active participants and collaborators enabled the teacher to plan lessons where a range of communicative functions were initiated and sustained by the learners. Autonomy and self-direction were fostered throughout the one-year observation period in which classes were monitored and observed.

\section{Method}

The participants in this study were five teachers in different subject areas, Mathematics, Science, English, Italian and Social Studies. Each teacher taught a small class of students, with the students distributed across several distant sites. All students participating in the study were in the first year at secondary school and aged between 12.5 and 13.5 years. The study focussed on two important aspects of teaching for higher order thinking, teacher planning for higher order thinking, though specification of lesson formats and teaching strategies that would support these outcomes, and the adoption of pedagogies that would facilitate the development and maintenance of higher order thinking and students' awareness of their own thinking.

Teachers utilised the curriculum guidelines to develop programs to meet the needs of their students, while applying the potentialities of the technology to achieve an appropriate level of communication and create a context where higher levels of cognition could flourish. The research involved both naturalistic observation of classrooms and diagnosis of teachers' pedagogies and students' learning processes.

\section{Research phases}

The research was conducted in three phases.

Phase 1: During this stage classes were observed and teacher and student behaviours were monitored and recorded on videotape. Two hours of classroom teaching were videotaped for each subject. Lessons were then fully transcribed to include activities, technology use and 
interactions of students. At the end of this ten week phase, the nature of each classroom environment was analysed and teachers were able to consider the appropriateness of strategies they had employed.

Table 1: A framework for investigating interactions in classrooms

\begin{tabular}{|c|c|c|}
\hline $\begin{array}{c}\text { Type of } \\
\text { interaction }\end{array}$ & Description & Example \\
\hline non task talk & $\begin{array}{l}\text { participants engaging in social } \\
\text { or administrative talk not } \\
\text { relevant to the learning task }\end{array}$ & $\begin{array}{l}\text { T: Hello Vicky how are you? } \\
\text { S: Very well thank you. } \\
\text { T: Good. So how was your } \\
\text { homework? }\end{array}$ \\
\hline procedural & $\begin{array}{l}\text { teacher/student dialogue } \\
\text { involving information exchange } \\
\text { on course requirements or } \\
\text { homework and procedures }\end{array}$ & $\begin{array}{l}\text { S: Teacher can you tell me how } \\
\text { many pages you want us to } \\
\text { write? } \\
\text { T: I'm looking for about } 2 \text { pages in } \\
\text { total. } \\
\text { S: Can we do more? }\end{array}$ \\
\hline expository & $\begin{array}{l}\text { student or teacher } \\
\text { demonstrating knowledge or } \\
\text { skill in response to a direct } \\
\text { request from another }\end{array}$ & $\begin{array}{l}\text { T: Can anyone tell me word for ice- } \\
\text { cream in Italian? } \\
\text { S: Is it gelato? } \\
\text { T: Fantastic }\end{array}$ \\
\hline feedback & $\begin{array}{l}\text { teacher using student } \\
\text { responses to give feedback, } \\
\text { praise or reinforcement }\end{array}$ & $\begin{array}{l}\text { T: This is how we place our fingers } \\
\text { to play the note A. Can you play } \\
\text { for me Mandy? } \\
\text { S: (plays the note on her recorder) } \\
\text { T: That was good but you have to } \\
\text { blow a bit harder }\end{array}$ \\
\hline $\begin{array}{l}\text { Cognitive } \\
\text { support }\end{array}$ & $\begin{array}{l}\text { teacher providing constructive } \\
\text { feedback to a student } \\
\text { response causing the student } \\
\text { to reflect and to consider an } \\
\text { alternative perspective/reality }\end{array}$ & $\begin{array}{l}\text { T: Can you explain what you think } \\
\text { was the main reason for his } \\
\text { actions? } \\
\text { S: He was angry and wanted to get } \\
\text { even. } \\
\text { T: But was that all? What about his } \\
\text { wish to improve his position and } \\
\text { standing? } \\
\text { S: I suppose he did but I thought } \\
\text { that he would have done it } \\
\text { differently. }\end{array}$ \\
\hline control & $\begin{array}{l}\text { teacher issuing a directive or } \\
\text { instruction to students that } \\
\text { would limit interpretation of the } \\
\text { task }\end{array}$ & $\begin{array}{l}\text { T: OK everybody, write "speech " in } \\
\text { your graphic outline of culture. }\end{array}$ \\
\hline $\begin{array}{l}\text { reconstruc- } \\
\text { tion }\end{array}$ & $\begin{array}{l}\text { teacher repeats the student's } \\
\text { response, but changes the } \\
\text { wording so that it is more } \\
\text { correct }\end{array}$ & $\begin{array}{l}\text { T: So why are trees useful to us? } \\
\text { S: They are home for animals } \\
\text { T: Yes, good. They are the natural } \\
\text { habitat for animals. }\end{array}$ \\
\hline
\end{tabular}


Phase 2: In collaboration with the researchers, a training session was planned to enable teachers to develop strategies and language protocols in their classrooms which would substantially improve students' independent thinking skills. Teachers were then videotaped and interviewed for 2 lessons during another term of 10 weeks as they sought to implement their changed teaching practices and to foster more occurrences of higher order thinking.

Phase 3: Teachers were shown the outcomes of their changed practices and caused to reflect on their achievement of increased higher order thinking and how this could be further enhanced. Once again, two lessons of each teacher were videotaped during a third term of teaching in order to explore the nature of the teaching and learning environments.

\section{Instrumentation for analysis of data}

A classroom observation instrument that served as an indicator of teacher pedagogy was developed and used to provide descriptors of the teaching and learning environment. A number of approaches have been proposed for analysing interactions in classrooms and learning environments, such as discourse analysis, systematic observation and coding schemes (McLoughlin \& Oliver, 1995). Discourse analysis of communicative interactions was chosen for the present study because of its potential to provide a multilevel understanding of the learning process. A framework of seven forms of interaction and discourse was chosen for the present study because of its potential to provide a multilevel understanding of the learning process. Table 1 presents an overview of the categories used to code teacher-student talk.

For analysis of talk, the categories of non-task, procedural and expository talk were used, as these were reciprocated by students when teacher initiated the dialogue. The other major category of student talk was higher order thinking, which was coded according to whether higher order thinking was evident in the discourse. Four dimensions of higher order thinking were identified through language indicators of reasoning (Perkins, 1997) where students cited evidence for views held, demonstrated inquiry and reflective skills and interpreted concepts throughout the lesson.

\section{Classroom observations in Phase 1}

The initial observations of teachers working in classrooms showed that much of the talk that occurred was expository, procedural and control 
based. Didactic patterns were evident in the data, where teachers asked the questions and students responded with short factual answers. Descriptive statistics on each of the categories are displayed in Table 2.

Table 2 illustrates that much of the teacher talk that occurred in the observation phase was to do with non-task, or procedural matters, such as management, roll call, disciplinary issues and homework. The proportion of teacher talk that related to cognitive support and development of conceptual understanding was relatively low, with the maximum being $20 \%$ in the Mathematics classes.

Initial observations of the classrooms in phase 1 of the study also revealed that students had:

- dependent roles in the dialogue where they responded but did not initiate;

- limited opportunities to talk and practice skills, and engage in social talk;

- lack of meaningful activities to enable them to express personal views, opinions and engage in informal reasoning about their own educational experiences.

Table 2: Mean percentages of teacher talk by category in phase 1

\begin{tabular}{|c|c|c|c|c|c|c|c|c|}
\hline Lesson & $\begin{array}{c}\text { non task } \\
\%\end{array}$ & $\begin{array}{c}\text { procedural } \\
\%\end{array}$ & $\begin{array}{c}\text { expository } \\
\%\end{array}$ & $\begin{array}{c}\text { control } \\
\%\end{array}$ & $\begin{array}{c}\text { reconstr- } \\
\text { uction } \%\end{array}$ & $\begin{array}{c}\text { cognitive } \\
\%\end{array}$ & $\begin{array}{c}\text { feedback } \\
\%\end{array}$ & $\begin{array}{c}\text { Total } \\
\%\end{array}$ \\
\hline $\begin{array}{c}\text { Maths } \\
1 \& 2\end{array}$ & 13 & 18 & 21 & 14.5 & 3.5 & 20 & 10 & 100 \\
\hline $\begin{array}{c}\text { English } \\
1 \& 2\end{array}$ & 12 & 19 & 21.5 & 20.5 & 4 & 17 & 7 & 100 \\
\hline $\begin{array}{c}\text { Science } \\
1 \& 2\end{array}$ & 13.5 & 25 & 21.5 & 15 & 2 & 17 & 6 & 100 \\
\hline $\begin{array}{c}\text { Italian } \\
\text { S. Studies } \\
1 \text { \& } 2\end{array}$ & 10 & 21 & 22 & 17 & 2.5 & 16 & 11.5 & 100 \\
\hline
\end{tabular}

\section{Phase 2}

To overcome these limitations, the teachers and researchers planned to develop strategies to assist the students to become independent thinkers and develop rational forms of talk in the classrooms. The teachers recognised the need to:

- be explicit in stating the goals and objective of each lesson; 
- develop a lesson plan for each lesson stating student thinking outcomes;

- build into the lesson opportunities for students to respond to classroom experiences and reflect on these;

- encourage learners to judge the purpose and effect of their own learning, and make personal statements about their classroom experiences.

Teachers were encouraged to adopt a variety of strategies based on modelling, scaffolding and encouragement of analysis, questioning and critical thinking. Instructional approaches were based on the provision of supportive social contexts for learning. Videotaping of lessons continued during the second semester, following the intervention.

The principal changes from phase 1 to phase 2 phase were that :

- there was an increase in cognitive support for students across all subject areas;

- the proportion of higher order thinking in student talk increased;

- the amount of non-task talk and procedural talk decreased.

The types of teacher talk which decreased were those related to non-task or routine, and management issues (Table 3).

Table 3: Mean percentages changes in teacher talk by category from phase 1 to phase 2 in all subjects

\begin{tabular}{|c|c|c|c|c|c|c|c|}
\hline Stage 1-2 & $\begin{array}{c}\text { non task } \\
\%\end{array}$ & $\begin{array}{c}\text { procedural } \\
\%\end{array}$ & $\begin{array}{c}\text { expository } \\
\%\end{array}$ & $\begin{array}{c}\text { control } \\
\%\end{array}$ & $\begin{array}{c}\text { reconstruc- } \\
\text { tion } \%\end{array}$ & $\begin{array}{c}\text { cognitive } \\
\%\end{array}$ & $\begin{array}{c}\text { feedback } \\
\%\end{array}$ \\
\hline Maths & -4 & -6 & -2 & -3 & -.5 & +7.5 & +4.5 \\
\hline English & -5 & -3 & -3.5 & -21.5 & +1.5 & +23 & +4 \\
\hline Science & -3 & -10 & -3 & 0 & 0 & +9 & +4 \\
\hline Italian & -2 & -8 & -4 & -6 & -1 & +10 & +3 \\
\hline S. Studies & -4 & -20 & -5 & -9 & +2 & +18.5 & +2.5 \\
\hline
\end{tabular}

\section{Phase 3}

Following the intervention, changes were observed to occur in the pattern of teacher talk and student talk. In phase 3 the pattern of pedagogic support was that teachers continued to support thinking skills in students by offering a range of scaffolds, such as asking reflective questions, encouraging discussion, promoting reflection, and promoting collaborative questioning which enabled students to reflect and elaborate on their own thinking processes. 
Table 4 shows the mean percentage changes in teacher talk from phase 2 to phase 3, when teachers were implementing their process-based strategies for higher order thinking.

Table 4: Mean percentages change in teacher talk from phase 2 to phase 3

\begin{tabular}{|c|c|c|c|c|c|c|c|}
\hline Phase 2-3 & $\begin{array}{c}\text { non task } \\
\%\end{array}$ & $\begin{array}{c}\text { procedural } \\
\%\end{array}$ & $\begin{array}{c}\text { expository } \\
\%\end{array}$ & $\begin{array}{c}\text { control } \\
\%\end{array}$ & $\begin{array}{c}\text { reconstruc- } \\
\text { tion } \%\end{array}$ & $\begin{array}{c}\text { cognitive } \\
\%\end{array}$ & $\begin{array}{c}\text { feedback } \\
\%\end{array}$ \\
\hline Maths & +7 & -4 & -1 & -2.5 & +0.5 & +0.5 & 0 \\
\hline English & +1 & -1 & -2.5 & -2.5 & -1.5 & +2 & 0 \\
\hline Science & -1.5 & -1.5 & -2 & 0 & +6 & +1 & -3 \\
\hline Italian & -1 & -3 & -3 & -1 & +2 & +3 & +1 \\
\hline S. Studies & +1 & +3.5 & -3.5 & -4 & -0.5 & +4.5 & +1.5 \\
\hline
\end{tabular}

The data clearly showed that for teachers, the proportion of cognitive talk devoted to supporting thinking and reasoning improved from phase 1 of the study and remained reasonably stable for the two terms following the training program. Student talk also showed increases in higher order thinking from phase 1 to phase 3.

\section{Pedagogical techniques and roles in the extended classroom}

Teachers were found to have adopted various pedagogical techniques in order to achieve their objective of higher order thinking. Observations of the classrooms suggested that the pattern of interaction engaged as the term progressed, and that teachers became less controlling, or less explicit in their approaches. Research on classrooms has shown that teachers engage in talk to a greater extent than students, and that such roles tend to be interrogative (Carlsen, 1991). In contrast, teaching for higher order thinking meant that teachers had to capitalise on the provision of opportunities for children to cooperate, to explore and to engage in peer review of the ideas adopted.

Discourse patterns displayed in the transcripts of teacher talk showed that teachers fulfilled two basic functions, organisational roles and pedagogical-emotional roles. Table 5 shows that teacher fulfilled a number of functions in their talk, which served both pedagogical and sociocognitive functions. In addition there were other functions observed, related to the control or management of the class which decreased in frequency as the term progressed. 
Table 5: Pedagogical roles in the extended classroom model

\begin{tabular}{|l|l|l|}
\hline $\begin{array}{c}\text { Pedagogical roles of } \\
\text { teachers }\end{array}$ & \multicolumn{1}{|c|}{$\begin{array}{c}\text { Organisational } \\
\text { function }\end{array}$} & \multicolumn{1}{c|}{$\begin{array}{c}\text { Socio-cognitive } \\
\text { function }\end{array}$} \\
\hline $\begin{array}{l}\text { control/management of } \\
\text { turns }\end{array}$ & $\begin{array}{l}\text { setting up and managing } \\
\text { the classroom }\end{array}$ & $\begin{array}{l}\text { ensure full participation of } \\
\text { all students }\end{array}$ \\
\hline $\begin{array}{l}\text { co-respondent and } \\
\text { conversational partner }\end{array}$ & $\begin{array}{l}\text { commenting and } \\
\text { participating in talk }\end{array}$ & $\begin{array}{l}\text { creation of interactive, } \\
\text { open and friendly } \\
\text { ambience }\end{array}$ \\
\hline $\begin{array}{l}\text { providing positive } \\
\text { evaluative feedback }\end{array}$ & focus on relevant issues & $\begin{array}{l}\text { summarise discussion; } \\
\text { prompt students to make } \\
\text { their contributions relevant }\end{array}$ \\
\hline reflective questioning & $\begin{array}{l}\text { promote critical } \\
\text { discussant behaviours }\end{array}$ & $\begin{array}{l}\text { provoke thought, deeper } \\
\text { explanation and meaning }\end{array}$ \\
\hline
\end{tabular}

Accompanying the changes in pedagogic roles, technology was used initially by teachers to display ideas and to introduce new concepts. As the term progressed, the interactive features of the technology were used to achieve collaborative dialogue and thereby to achieve higher order thinking. Teacher roles became more participatory and less didactic and learner control of the technology was encouraged. Students achieved the outcome of higher order thinking and this was reflected in classroom dialogue, independence of thought and the growth of autonomy.

\section{Conclusion}

The results from the study were extremely positive in that they demonstrated the capacity of audiographics learning environments to support strong levels of higher order thinking through appropriate forms of teacher discourse and participatory roles for students.

One finding that was of interest to the researchers was the role of intentionality in support higher order cognition. It was made evident in the study that if teachers are to cultivate higher order thinking in the classroom, they need to have a clear instructional intention to facilitate its occurrence, and to plan for it. They also need to encourage language use, model appropriate skills and create conditions in the classroom for the transition from regulation by other to self-regulation. Our study confirmed that when teachers planned and acted in such ways, higher order cognition emerged as an identifiable outcome in the learning environment. 
The study found that technology use can enhance communication and reasoning if it is used, not a device to display syllabus content, but as a cognitive tool to enhance understanding. This was achieved by teachers in the distance classrooms increasingly engaging students in cognitive talk, rather than procedural and expository. In addition, teachers adopted strategies whereby their management role became secondary to that of reflective questioning and conversational engagement. Teachers' use of the two-way audio technology in these audiographics environments was one factor in the classrooms of this study which appeared to hold considerable potential to enhance learning to achieve higher order thinking outcomes.

The implications of the study are essentially to emphasise the use of the audiographic conferencing to foster collaboration and dialogue among students. Socio-cognitive pedagogies were applied by teachers in order to sustain collaborative dialogue and open communication among students. The technology was used as a cognitive and social tool to augment discussion, to display ideas and to enable collaborative construction of ideas across the geographically separated classrooms. This study provides insights into how learning in a distributed classroom can lead to improved cognitive outcomes for students, if pedagogic practices and technology use combine to support dialogue and collaboration.

\section{References}

Burge, E. J., \& Roberts, J. M. (1993). Classrooms with a difference: a practical guide to the use of conferencing technologies. Ontario: University of Toronto Press.

Carlsen, W. S. (1991). Questioning in classrooms: a sociolinguistic perspective. Review of Educational Research, 61(157-178).

Crook, C. (1994). Computers and the collaborative experience of learning. London: Routledge.

EDWA (1996). Curriculum framework documents. Perth: Education Department.

Greeno, J. G. (1997). On claims that answer the wrong questions. Educational Researcher, 26(1), 5-17.

Gunawardena, C. (1992). Changing faculty roles for audiographics and online teaching. The American Journal of Distance Education, 6 (3), 58-71.

Laurillard, D. (1995). Multimedia and the changing experience of the learner. British Journal of Educational Technology, 26(3), 179-189. 
McLoughlin, C., \& Oliver, R. (1995a). Analysing interactions in technology supported learning environments. In R. Oliver \& M. Wild (Ed.), Learning without limits, 2 (pp. 49-62). Perth, WA: ECAWA.

McLoughlin, C., Oliver, R., \& Wood, D. (1997). Teaching and learning in telematics environments: Fostering higher level thinking outcomes. Australian Educational Computing, 12(1), 9-15.

Oliver, R., \& McLoughlin, C. (1997). Interactions in audiographics teaching and learning environments. The American Journal of Distance Education, 11(1), 3455.

Oliver, R., \& Reeves, T. (1994). Telematics in rural education. Perth: Intech Innovations.

Paul, R. (1993). Critical thinking. Melbourne: Hawker Brownlow.

Perkins, D. N. (1997). Epistemic games. International Journal of Educational Research, 27(1), 49-61.

Vygotsky, L. (1978). Mind in society: the development of higher psychological processes. Cambridge MA: Harvard University Press. (Original material published in 1930, 1933 and 1935). 